\title{
EFEK THRESHOLD INFLASI TERHADAP PERTUMBUHAN EKONOMI REGIONAL DI INDONESIA
}

\author{
THRESHOLD INFLATION EFFECTS \\ ON REGIONAL ECONOMIC GROWTH IN INDONESIA
}

\author{
Adam Luthfi Kusumatrisna ${ }^{1}$, Iman Sugema ${ }^{2}$, Syamsul H. Pasaribu ${ }^{3}$ \\ ${ }^{1}$ Sekolah Pasca Sarjana Ilmu Ekonomi Institut Pertanian Bogor dan Badan Pusat Statistik, Jakarta, Indonesia \\ adam.luthfi@bps.go.id; \\ ${ }^{2}$ Sekolah Pasca Sarjana Ilmu Ekonomi Institut Pertanian Bogor, Bogor, Indonesia \\ isugema@gmail.com; \\ ${ }^{3}$ Sekolah Pasca Sarjana Ilmu Ekonomi Institut Pertanian Bogor, Bogor, Indonesia \\ syamsulhp@gmail.com.
}

\begin{abstract}
Abstrak
Penelitian terbaru menyatakan bahwa hubungan antara inflasi dan pertumbuhan ekonomi tidaklah linier. Ketika inflasi melebihi ambang batas (threshold) tertentu, akan berdampak negatif terhadap pertumbuhan ekonomi. Penelitian ini bertujuan untuk menyelidiki hubungan linear dan non-linear antara inflasi dan pertumbuhan ekonomi di Indonesia menggunakan data panel provinsi. Hubungan linier diuji menggunakan panel fixed effect model sementara hubungan non-linear menggunakan panel threshold fixed effect model. Saat dilakukan uji secara linear, inflasi di Indonesia memiliki efek negatif pada pertumbuhan ekonomi begitu juga dengan pertumbuhan rasio pengeluaran pemerintah dan pertumbuhan penduduk. Sementara pertumbuhan investasi dan pertumbuhan keterbukaan ekonomi memiliki efek positif terhadap pertumbuhan ekonomi. Ketika melakukan uji non-linear, inflasi di Indonesia berdampak negatif terhadap pertumbuhan ekonomi hanya ketika melebihi 9,57 dan 9,59 persen. Sementara itu saat inflasi melebihi 5,09 persen, pertumbuhan ekonomi di Indonesia melambat. Kebijakan pengendalian inflasi tetap harus dilakukan untuk mengurangi dampak buruk inflasi, karena inflasi yang tinggi dan berfluktuasi tidak baik bagi perekonomian. Studi ini menyarankan pihak terkait seperti Bank Indonesia (BI) dan Tim Pemantauan dan Pengendalian Inflasi Daerah (TPID) untuk berhati-hati saat inflasi mulai melebihi angka 5,09 persen dan waspada saat inflasi melebihi angka 9,57 persen dan 9,59 persen.
\end{abstract}

Kata kunci: Ambang Batas, Inflasi, Pertumbuhan Ekonomi

Klasifikasi JEL: E31, O47, C24

\begin{abstract}
Recent research states that relationship between inflation and economic growth is not linear. When inflation exceeds threshold, it will negatively affect economic growth. This study aims to investigate a linear and non-linear relationship between inflation and economic growth in Indonesia using provincial panel data. Linear relationships are tested using a fixed effect panel while non-linear relationships use the threshold fixed effect panel. Linear relationship of inflation in Indonesia has a negative effect on economic growth as well as government expenditure ratio growth and population growth, while investment growth and economic openness growth have a positive effect on economic growth. When conducting non-linear test, inflation in Indonesia negatively affected economic growth when it exceeded 9,57 and 9.59 percent. Meanwhile, when inflation exceeds 5.09 percent, economic growth in Indonesia has slowed. Inflation control policies must still be done to reduce the adverse effects of inflation, because high and fluctuating inflation is not good for the economy. This study advises stakeholders such as Bank Indonesia (BI) and the Regional Inflation Monitoring and Control Team (TPID) to be cautious when inflation starts to exceed 5.09 percent and be alert when inflation exceeds 9.57 percent and 9.59 percent.
\end{abstract}

Keywords: Threshold, Inflation, Economic Growth

JEL Classification : E31, O47, C24 


\section{PENDAHULUAN}

Pendapat yang berkembang di kalangan ekonom menyatakan bahwa inflasi yang rendah dan terkendali merupakan syarat bagi pertumbuhan ekonomi yang berkelanjutan sesuai dengan semangat Sustainable Development Goals (SDGs). Fenomena kebijakan pengendalian inflasi mulai mengemuka sejak dua dasawarsa terakhir (Warjiyo dan Juhro, 2016). Kebijakan pengendalian inflasi di Indonesia diwujudkan dalam penerapan kebijakan Inflation Targeting Framework(ITF). Pada dasarnya ITF merupakan suatu kebijakan untuk menjaga inflasi tetap berada pada level tertentu, yaitu 3-5 persen untuk jangka panjang dan 4-10 persen untuk jangka pendek (Chowdury dan Ham 2009).

Perkembangan inflasi nasional di Indonesia tidak terlepas dari dinamika perkembangan inflasi yang terjadi di daerah. Inflasi nasional merupakan hasil penggabungan (agregasi) dari inflasi di daerah dengan pembobotan tertentu. Bobot setiap kota yang menjadi sampel penghitungan inflasi diperoleh dari Survei Biaya Hidup (SBH). Salah satu peran serta pemerintah daerah dalam mengendalikan inflasi adalah dengan membentuk Tim Pemantauan dan Pengendalian Inflasi Daerah (TPID). Dengan adanya TPID diharapkan koordinasi antara stakeholder terkait dapat berjalan lebih baik sehingga kestabilan harga dapat terwujud pada level daerah di seluruh Indonesia.
Gambar 1 menunjukkan plot inflasi dan pertumbuhan ekonomi di Indonesia selama 23 tahun, dari tahun 1994 hingga 2017. Bagian a dari gambar 1 menunjukkan plot inflasi dan pertumbuhan ekonomi secara utuh dari tahun 1994 sampai dengan 2017, sedangkan bagian b tidak memasukkan inflasi dan pertumbuhan ekonomi tahun 1998 untuk melihat pola kedua indikator tersebut dengan lebih jelas.

Perekonomian Indonesia pernah terpuruk pada tahun 1998, inflasi melambung hingga 77,63 persen dan pertumbuhan ekonomi terperosok hingga minus 13 persen seperti yang terlihat pada gambar 1a. Hal tersebut disebabkan oleh goncangan eksternal yaitu krisis keuangan Asia pada tahun 1997-1999. Pada saat itu tidak terjadi hiperinflasi karena Pemerintah pada akhirnya melakukan kebijakan stabilisasi perekonomian yang didukung IMF.

Inflasi cukup tinggi terjadi di tahun 20002001, 2005-2006, dan 2008. Tingginya inflasi sesudah krisis tersebut diduga banyak dipengaruhi kondisi sosial politik yang belum stabil sehingga mempengaruhi ekspektasi inflasi masyarakat. Selain itu melambungnya harga minyak dunia, kenaikan harga BBM domestik pada bulan Oktober 2005, depresiasi nilai tukar rupiah serta gangguan pasokan dan distribusi turut berkontribusi dalam memberikan tekanan kuat terhadap inflasi.

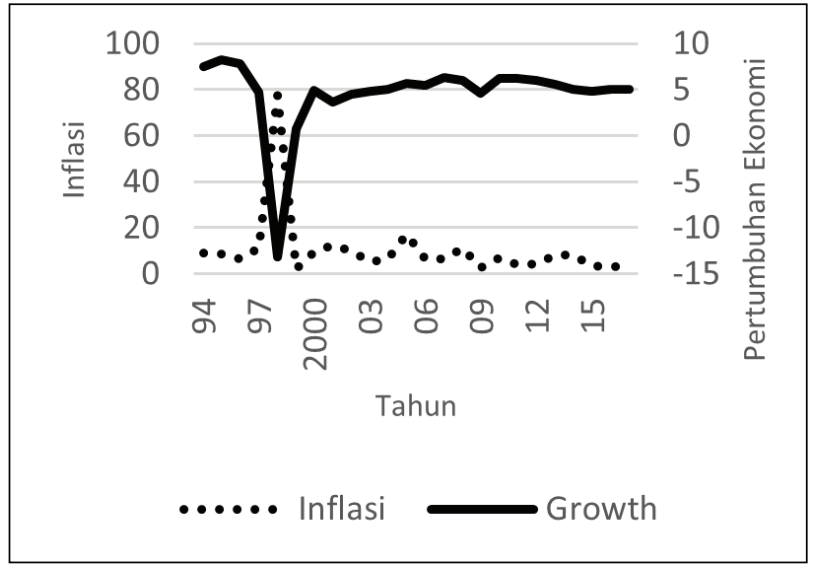

a. Memasukkan Tahun 1998

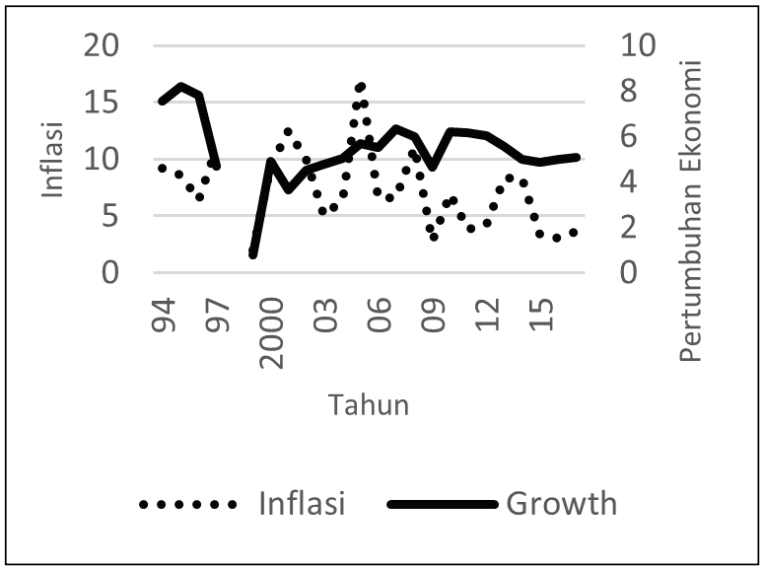

b. Tanpa Memasukkan Tahun 1998

Gambar 1. Inflasi dan Pertumbuhan Ekonomi di Indonesia Tahun 1994-2017 
Penelitian terbaru seperti yang dilakukan Widaryoko (2013) dan Aziz (2016) menyatakan bahwa hubungan antara inflasi dan pertumbuhan ekonomi tidaklah linier. Ketika inflasi melebihi ambang batas tertentu, akan berdampak negatif terhadap pertumbuhan ekonomi. Beberapa penelitian telah meneliti hubungan antara inflasi dan pertumbuhan ekonomi dan mencari titik ambang batasnya, tetapi masih sedikit studi yang meneliti hubungan antara dua indikator makroekonomi tersebut pada level suatu negara dengan data panel. Kebanyakan penelitian menggunakan panel data antar negara, dikelompokkan menjadi negara berkembang dan negara maju. Penelitian yang fokus meneliti fenomena tersebut di Indonesia mayoritas menggunakan data time series (Chowdurry dan Siregar, 2004; Chowdurry dan Ham, 2009; Widaryoko, 2013).

Aziz (2016) meneliti hubungan inflasi dengan pertumbuhan ekonomi di Indonesia menggunakan data panel provinsi untuk rentang waktu tahun 2010 hingga 2016. Aziz (2016) berhasil menghitung threshold inflasi sebesar 4,64 persen. Penelitian ini akan mengembangkan studi yang dilakukan oleh Aziz (2016) dengan menambahkan rentang waktu analisis mulai dari tahun 1994 hingga 2017. Hal ini dilakukan supaya dapat menangkap pengaruh dari krisis ekonomi yang terjadi pada tahun 1998 .

\section{TINJAUAN PUSTAKA}

Adam Smith merupakan ekonom yang pertama kali mengemukakan dasar teori pertumbuhan. Smith mengemukakan bahwa output merupakan fungsi dari kapital atau investasi, tenaga kerja, serta tanah. Pengaruh inflasi akan berdampak pada tingginya upah sehingga akan menghambat aktivitas produksi berujung pada melambatnya pertumbuhan ekonomi. Kesimpulannya inflasi diindikasikan memiliki hubungan negatif terhadap pertumbuhan ekonomi. Menurut teori pertumbuhan endogen, skala ekonomi, increasing return of scale dan teknologi berperan penting dalam pertumbuhan output. Dalam teori ini, pertumbuhan output sangat tergantung pada variabel tingkat pengembalian modal. Variabel seperti inflasi dapat menurunkan tingkat pengembalian modal sehingga akan mengurangi akumulasi modal pada akhirnya menekan output. Beberapa penelitian menghasilkan kesimpulan yang berbeda tentang bagaimana hubungan linear antara inflasi dengan pertumbuhan ekonomi. Pertama, inflasi berpengaruh netral atau tidak berpengaruh terhadap pertumbuhan ekonomi (Cameron et. al, 1998; Dorrance, 1963; Sidrauski, 1967). Kedua, inflasi berpengaruh positif terhadap pertumbuhan ekonomi (Mallik dan Chowdurry, 2001; Shi, 1999; Tobin, 1965). Terakhir, inflasi berhubungan negatif dengan pertumbuhan ekonomi (Andres dan Hernando, 1997; Barro, 1996; De Greorgio, 1992; Friedman, 1956; Gylfason, 1998; Saed, 2007; Stockham, 1981).

Stanley Fischer merupakan peneliti yang mengawali studi hubungan tidak linear antara inflasi dengan pertumbuhan ekonomi pada tahun 1993. Menggunakan metode spline regression pada data 93 negara maju dan berkembang, dari tahun 1965 hingga 1990, membuktikan bahwa inflasi yang tinggi (diatas 40 persen) memiliki dampak negatif yang lebih besar dibanding inflasi yang rendah. Tabel 1 menjabarkan penelitian yang mencari threshold inflasi yang berfokus di Indonesia.

Threshold inflasi 32 negara Asia berhasil ditemukan oleh Vinayagathasan pada tahun 2013, titik threshold yang ditemukan sebesar 5,43 persen dengan periode waktu penelitian 1980 hingga 2009. Threshold di India sebesar 4 persen berhasil ditemukan oleh Behera pada tahun 2014, dengan rentang waktu penelitian 1990 sampai dengan 2013. Sedangkan Ndoricimpa (2017) berhasil menemukan nilai threshold untuk negara-negara di Afrika sebesar 6,67 persen. Sementara untuk negara dengan kategori low income di Afrika titik threshold yang didapatkan sebesar 8,87 persen, untuk middle income sebesar 6,46 persen. Penelitian tersebut dilakukan pada 47 negara di Afrika, periode waktu penelitian setiap negara berbeda, tergantung ketersediaan data. 
Tabel 1. Studi Pencarian Threshold Inflasi yang Fokus Meneliti Indonesia

\begin{tabular}{|c|c|c|c|c|c|}
\hline $\begin{array}{c}\text { Peneliti dan } \\
\text { Tahun }\end{array}$ & Metode & Periode Studi & Model & $\begin{array}{l}\text { Nilai } \\
\text { Threshold } \\
\text { Inflasi }\end{array}$ & Kesimpulan \\
\hline (1) & (2) & (3) & (4) & (5) & (6) \\
\hline $\begin{array}{l}\text { Chowdurry dan } \\
\text { Siregar (2004) }\end{array}$ & $\begin{array}{l}\text { Kausalitas } \\
\text { Granger dan } \\
\text { Regresi Kua- } \\
\text { dratik }\end{array}$ & 1970-1996 & Non-linier & $25,18 \%$ & $\begin{array}{l}\text { Terdapat hubungan kausalitas dua } \\
\text { arah antara inflasi dengan per- } \\
\text { tumbuhan ekonomi, inflasi diatas } \\
25,18 \text { persen signifikan berpenga- } \\
\text { ruh negatif terhadap pertumbuhan } \\
\text { ekonomi }\end{array}$ \\
\hline $\begin{array}{l}\text { Chowdhury \& } \\
\text { Ham, } 2009\end{array}$ & $\begin{array}{l}\text { Threshold } \\
\text { vector au- } \\
\text { toregressions } \\
\text { (TVAR) }\end{array}$ & $1972-2007$ & Linier & $8,5-11 \%$ & $\begin{array}{l}\text { Inflasi diatas } 11 \text { persen signifikan } \\
\text { berpengaruh negatif terhadap per- } \\
\text { tumbuhan ekonomi }\end{array}$ \\
\hline $\begin{array}{l}\text { Widaryoko } \\
\text { (2013) }\end{array}$ & $\begin{array}{l}\text { Regresi } \\
\text { Time Series } \\
\text { Berganda, } \\
\text { menggunakan } \\
\text { metode Han- } \\
\text { sen dan Khan } \\
\text { Senghaji }\end{array}$ & $1970-2012$ & Non-linier & $\begin{array}{l}7,11 \text { dan } \\
9,53 \%\end{array}$ & $\begin{array}{l}\text { Inflasi diatas nilai threshold signifi- } \\
\text { kan berpengaruh negatif terhadap } \\
\text { pertumbuhan ekonomi }\end{array}$ \\
\hline (Aziz, 2016) & Regresi Panel & 2010-2016 & Non-Linier & $4,64 \%$ & $\begin{array}{l}\text { Inflasi diatas nilai threshold signifi- } \\
\text { kan berpengaruh negatif terhadap } \\
\text { pertumbuhan ekonomi }\end{array}$ \\
\hline
\end{tabular}

Sumber: Kompilasi penulis dari berbagai penelitian

Beberapa teori ekonomi dan temuan empiris menyatakan bahwa inflasi tinggi berdampak buruk terhadap perekonomian, walaupun hubungan dari kedua variabel tersebut sebenarnya masih menjadi perdebatan. Indonesia pernah mengalami keterpurukan ekonomi sebagai akibat tingginya inflasi yang akhirnya mendorong pemerintah menerapkan kebijakan inflasi rendah. Kebijakan inflasi rendah tersebut tercakup dalam kerangka Inflation Targeting Framework (ITF), dimana pelaksanaannya dimulai sejak tahun 2006.

Dalam praktiknya pengendalian inflasi di Indonesia memunculkan dilema. Ketika inflasi ditekan hingga ke level rendah pertumbuhan ekonomi ternyata tidak terlalu tinggi. Gambar 2, kotak sebelah kiri menunjukkan kondisi gambaran inflasi sebelum pelaksanaan ITF setelah terjadi krisis 1998, berkisar pada angka 8.93 persen pada kondisi stabil (tidak mengalami krisis ekonomi). Sementara pertumbuhan ekonomi setelah krisis 1998 sebesar 4.19 persen. Setelah dilakukan kebijakan penerapan ITF, inflasi turun hingga 5.73 persen, namun pertumbuhan ekonomi hanya 5.54 persen. Kenaikan pertumbuhan ekonomi hanya 1.35 persen.

Hal ini kontradiktif dengan gagasan para ekonom yang pernah menyatakan bahwa inflasi rendah dan stabil dapat mendorong laju pertumbuhan ekonomi dengan cepat. Oleh karena itu perlu dikaji lebih dalam mengenai pengaruh inflasi terhadap pertumbuhan ekonomi serta nilai inflasi optimum yang sebaiknya diberlakukan di Indonesia, sehingga dapat dirumuskan suatu kebijakan yang optimal. Alur pemikiran dalam penelitian ini dapat dilihat pada Gambar 2. 


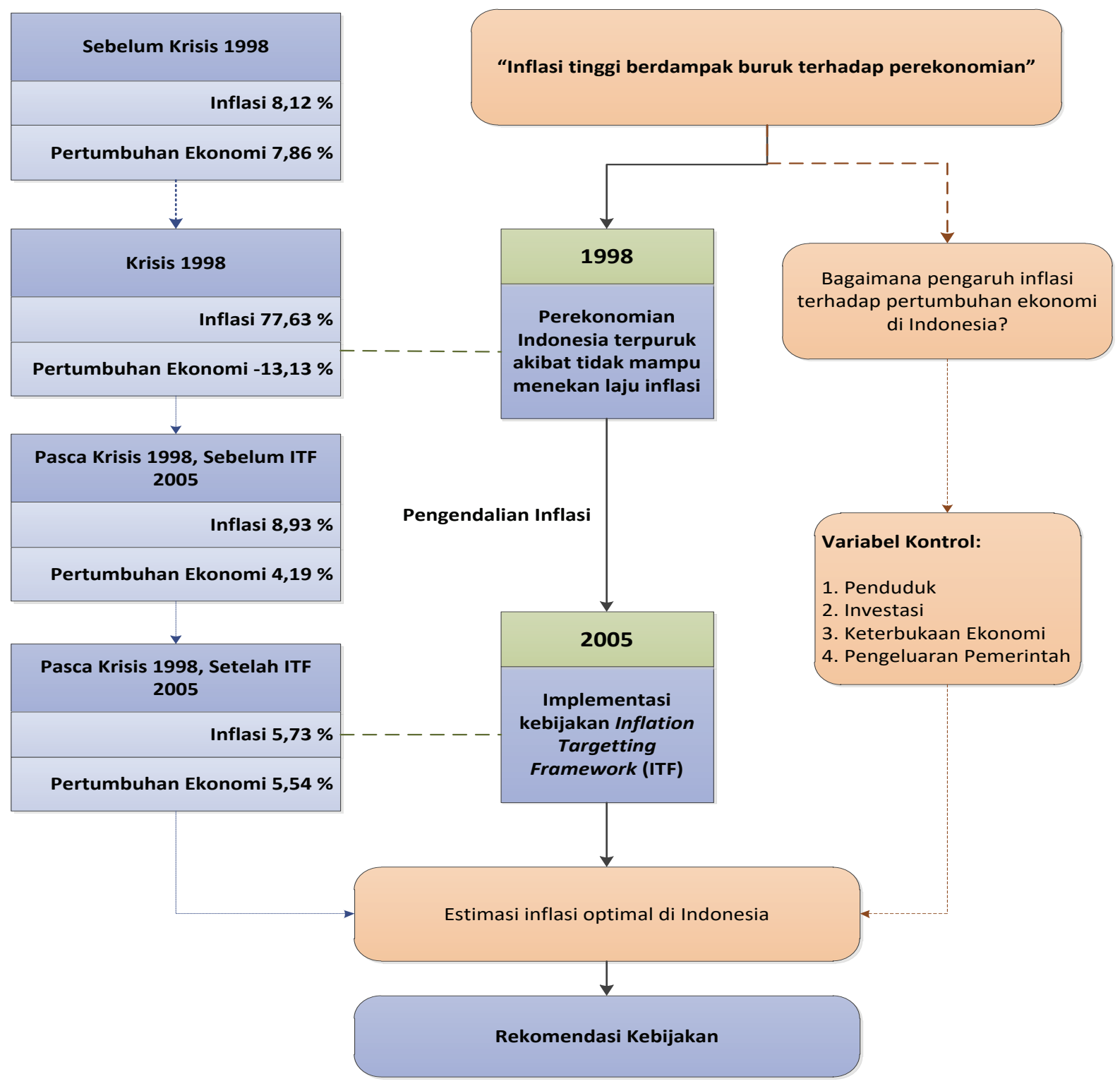

Gambar 2 Alur Kerangka Pemikiran

Berdasarkan permasalahan, tujuan dan alur kerangka pemikiran dalam penelitian ini, hipotesis penelitian yang dapat disusun antara lain:

1. Saat dilakukan uji linier, inflasi bisa berpengaruh positif, negatif, atau netral terhadap pertumbuhan ekonomi.

2. Saat dilakukan uji non-linier, inflasi berpengaruh positif atau netral terhadap pertumbuhan ekonomi hingga threshold tertentu, setelah threshold tertentu inflasi berpengaruh negatif terhadap pertumbuhan ekonomi.

\section{METODE PENELITIAN}

Penelitian ini menggunakan data panel 26 provinsi di Indonesia dari tahun 1994 hingga 2017 sesuai dengan ketersediaan data. Semua variabel yang digunakan dalam penelitian ini merupakan data sekunder yang bersumber dari Badan Pusat Statistik (BPS).

Pembagian Indonesia menjadi Kawasan Barat dan Timur berdasarkan penelitian Utari et al (2015). Kawasan Barat Indonesia meliputi Sumatera dan Jawa, sementara Kawasan Timur Indonesia meliputi Kalimantan, Sulawesi, Bali Nusa Tenggara dan Maluku Papua. 
Variabel yang digunakan adalah pertumbuhan PDRB perkapita sebagai pendekatan pertumbuhan ekonomi, inflasi, pertumbuhan rasio pengeluaran pemerintah, pertumbuhan penduduk, dan pertumbuhan investasi serta pertumbuhan keterbukaan ekonomi (openness).

Pertumbuhan PDRB perkapita diperoleh dari membagi PDRB dengan jumlah penduduk pertengahan tahun, kemudian dihitung pertumbuhannya. Data inflasi hanya tersedia pada level kota yang menjadi sampel Survei Biaya Hidup (SBH). Untuk memperoleh angka inflasi provinsi, dilakukan dengan rataan inflasi terboboti oleh masing-masing kota. Pertumbuhan investasi diperoleh dari pertumbuhan Pembentukan Modal Tetap Bruto (PMTB). Variabel keterbukaan ekonomi dihitung dari total nilai ekspor dan impor per provinsi dibagi total PDRB tiap provinsi.

Metode analisis yang digunakan untuk menjawab tujuan penelitian menggunakan analisis ekonometrika berupa panel fixed effect model dan panel threshold fixed effect model yang keduanya diestimasi dengan ordinary least square (OLS). Metode untuk mencari titik threshold mengacu kepada model Hansen (1999), dimana dalam model tersebut terbatas hanya pada panel fixed effect model. Perluasan metode menjadi random effect model terhalang masalah endogenitas dan hasilnya akan bias (Hansen, 1999).

Persamaan yang digunakan untuk melihat hubungan linier menggunakan panel fixed effect model adalah:

Growth $_{i t}=\beta_{0(i)}+\beta_{1}$ Inf $_{i t}+\beta_{2}$ Pop $_{i t}+$

$\beta_{3}$ Inv $_{i t}+\beta_{4}$ Open $_{i t}+\beta_{5}$ Gov $_{i t}+e_{i t}$

Sedangkan bentuk persamaan untuk melihat hubungan non linier dan mencari titik threshold adalah:

$$
\begin{aligned}
& \text { Growth }_{i t}=\beta_{6(i)}+\left(\beta_{7} \text { Inf }_{i t}+\beta_{8} \text { Pop }_{i t}+\beta_{9 \text { Invit }}\right. \\
& \left.+\beta_{10 \text { Govit }_{i t}}+\beta_{11} \text { Open }_{i t}\right) * \text { I }\left(\text { Inf }_{i t}<\gamma\right) \\
& +\left(\beta_{12} \text { Infit }_{1}+\beta_{13} \text { Pop }_{i t}+\beta_{14} \text { InVit }+\beta_{15} \text { Govit }_{\text {t }}\right. \\
& \left.\beta_{16} \text { Openit }^{*} \text { I (Inf } f_{i t} \geq Y\right)+e_{i t}
\end{aligned}
$$

dengan:

$$
\begin{aligned}
& \text { Growth }_{i t}=\text { pertumbuhan PDRB per kapita (persen) } \\
& \operatorname{Inf}_{i t}=\text { inflasi (persen) } \\
& \text { Pop }_{i t} \quad=\text { pertumbuhan penduduk (persen) } \\
& \text { Inv }_{i t} \quad=\text { pertumbuhan investasi (persen) }
\end{aligned}
$$

Gov $_{i t} \quad=$ pertumbuhan rasio pengeluaran pemerintah (persen)

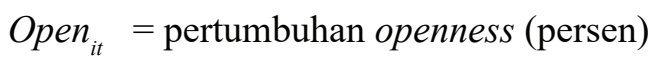

$\beta_{0}$ dan $\beta_{6}=$ intersep

$\beta_{1}, \beta_{2}, \beta_{3}, \beta_{4}, \beta_{5}, \beta_{7}, \beta_{8}, \beta_{9}, \beta_{10}, \beta_{11}, \beta_{12}, \beta_{13,}, \beta_{14} \beta_{15,} \beta_{16}=$ koefisien dugaan parameter

$$
\begin{aligned}
e_{i t} & =\text { residual } \\
\gamma & =\text { nilai threshold }
\end{aligned}
$$

Analisis regresi panel threshold merupakan pengembangan dari analisis regresi panel linier, yang pada intinya membagi unit estimasi menjadi dua rezim atau lebih. Untuk mengestimasi model, ada dua cara yang bisa dilakukan, yang pertama melalui ordinary least square (OLS) apabila nilai threshold sudah diketahui dan yang kedua dengan conditional least squares apabila nilai threshold belum diketahui. Prinsip dari conditional least squares adalah mencari nilai threshold dan nilai parameter slope secara bersama-sama. Hansen (1997) merekomendasikan model yang dipilih adalah model dengan nilai residual sum of squares (RSS) minimal. Enders (2015) menyarankan sekitar $15 \%$ nilai minimum dan $15 \%$ nilai maksimum pada variabel threshold tidak dimasukkan sebagai kandidat nilai threshold untuk menjamin kecukupan derajat bebas pada masing-masing rezim.

\section{HASIL DAN PEMBAHASAN}

Selama kurun waktu 1994 hingga 2017 pergerakan inflasi menunjukkan tren menurun. Setelah diberlakukan kebijakan Inflation Targeting Framework (ITF) pada tahun 2005 inflasi secara rata-rata berada pada angka 5-6 persen. Secara umum inflasi di Kawasan Timur Indonesia lebih tinggi dibandingkan Kawasan Barat Indonesia. Sementara pertumbuhan ekonomi per kapita di Kawasan Timur Indonesia lebih rendah dibandingkan Kawasan Barat Indonesia. Fenomena yang menarik terjadi saat krisis ekonomi 1998, pertumbuhan ekonomi Kawasan Barat Indonesia tertekan lebih dalam dibanding Kawasan Timur Indonesia. Fenomena ini kemungkinan dikarenakan perekonomian Kawasan Timur Indonesia lebih bertumpu kepada sektor pertanian, dimana sektor pertanian pada saat krisis 1998 terbukti mampu bertahan dari goncangan. 
Tabel 2. Inflasi dan Pertumbuhan Ekonomi 1994-2017

\begin{tabular}{lcccccc}
\hline \multirow{2}{*}{ Periode } & \multicolumn{2}{c}{ Kawasan Barat } & \multicolumn{2}{c}{ Kawasan Timur } & \multicolumn{2}{c}{ Indonesia } \\
\cline { 2 - 7 } & Inflasi & $\begin{array}{c}\text { Pertumbuhan } \\
\text { Ekonomi }\end{array}$ & Inflasi & $\begin{array}{c}\text { Pertumbuhan } \\
\text { Ekonomi }\end{array}$ & $\begin{array}{c}\text { Inflasi } \\
\text { Pertumbuhan } \\
\text { Ekonomi }\end{array}$ \\
\hline Sebelum Krisis 1998 & 8,48 & 5,69 & 8,11 & 5,92 & 8,85 & 5,73 \\
Krisis 1998 & 74,98 & $-12,20$ & 77,14 & $-2,66$ & 77,63 & $-10,41$ \\
Pasca Krisis Sebelum ITF & 7,42 & 1,31 & 7,70 & 0,80 & 7,57 & 1,20 \\
Pasca Krisis Setelah ITF & 5,68 & 4,15 & 6,17 & 3,22 & 5,73 & 3,95 \\
\hline
\end{tabular}

Sumber: BPS, diolah.

Catatan: ITF merupakan singkatan dari Inflation Targeting Framework.

Inflasi berpengaruh negatif signifikan terhadap pertumbuhan ekonomi disemua kawasan regional maupun pada level nasional. Setiap kenaikan inflasi sebesar 1 persen secara signifikan akan menyebabkan penurunan pertumbuhan ekonomi sebesar 0,12 persen untuk level nasional, 0,13 persen untuk kawasan barat Indonesia dan 0,11 persen untuk kawasan timur Indonesia. Hal tersebut sesuai dengan temuan Friedman (1956), Stockham (1981), De Greorgio (1992), Barro (1996), (Andres \& Hernando, 1997), Gylfason (1998), dan Saed (2007). Gokal dan Hanif (2004) menyatakan bahwa inflasi dapat menghambat optimalisasi produksi barang dan jasa karena tingginya biaya produksi. Pada akhirnya akan menurunkan output.

Pertumbuhan investasi berpengaruh positif signifikan terhadap pertumbuhan ekonomi disemua kawasan regional maupun pada level nasional. Setiap kenaikan investasi sebesar 1 persen secara signifikan akan menyebabkan peningkatan pertumbuhan ekonomi sebesar 0,12 persen untuk level nasional, 0,13 persen untuk kawasan barat Indonesia dan 0,12 persen untuk kawasan timur Indonesia. Teori yang dikemukakan Harrold-Domar dalam Todaro Smith (2006) menjelaskan bahwa strategi utama suatu negara untuk bertumbuh dalam tahapan mencapai tinggal landas adalah mobilisasi dana tabungan atau investasi, kondisi tersebut akan mempercepat pertumbuhan ekonomi.

Pertumbuhan penduduk berpengaruh negatif signifikan terhadap pertumbuhan ekonomi disemua kawasan regional maupun pada level nasional. Setiap kenaikan penduduk sebesar 1 persen secara signifikan akan menyebabkan penurunan pertumbuhan ekonomi sebesar 0,89 persen untuk level nasional, 0,55 persen untuk kawasan barat Indonesia dan 1,06 persen untuk kawasan timur Indonesia. Pemerintah sebaiknya menggalakkan kembali program keluarga berencana untuk menekan laju pertumbuhan penduduk.

Edward (1997) mengungkapkan bahwa keterbukaan ekonomi (openness) akan menstimulasi pertumbuhan ekonomi melalui peningkatan produktivitas, persaingan dan imitasi teknologi. Pertumbuhan openness berpengaruh

Tabel 3. Hasil Estimasi Model Linear Pertumbuhan Ekonomi

\begin{tabular}{|c|c|c|c|c|c|c|}
\hline \multirow{2}{*}{ Variabel } & \multicolumn{2}{|c|}{ Indonesia } & \multicolumn{2}{|c|}{ Kawasan Barat } & \multicolumn{2}{|c|}{ Kawasan Timur } \\
\hline & Koef. & Prob. & Koef. & Prob. & Koef. & Prob. \\
\hline Konstanta & 5,346 & 0,000 & 4,567 & 0,000 & 5,947 & 0,000 \\
\hline Inflasi & $-0,121$ & 0,000 & $-0,139$ & 0,000 & $-0,106$ & 0,000 \\
\hline Investasi & 0,123 & 0,000 & 0,128 & 0,000 & 0,117 & 0,000 \\
\hline Penduduk & $-0,892$ & 0,000 & $-0,549$ & 0,001 & $-1,058$ & 0,000 \\
\hline Openness & 0,032 & 0,000 & 0,022 & 0,035 & 0,035 & 0,000 \\
\hline GovSpending & $-0,215$ & 0,000 & $-0,131$ & 0,000 & $-0,291$ & 0,000 \\
\hline$R$-squared & \multicolumn{2}{|c|}{53,69} & \multicolumn{2}{|c|}{58,66} & \multicolumn{2}{|c|}{52,22} \\
\hline
\end{tabular}

Sumber: Hasil Olahan Penulis 
positif signifikan terhadap pertumbuhan ekonomi disemua kawasan regional maupun pada level nasional. Setiap kenaikan openness sebesar 1 persen secara signifikan akan menyebabkan peningkatan pertumbuhan ekonomi sebesar 0,03 persen untuk level nasional, 0,02 persen untuk kawasan barat Indonesia dan 0,04 persen untuk kawasan timur Indonesia. Keterbukaan ekonomi yang didekati dengan pertumbuhan openness berpengaruh positif terhadap pertumbuhan ekonomi. Hal ini sesuai dengan penelitian Vinayagathasan (2013).

Pertumbuhan rasio pengeluaran pemerintah berpengaruh negatif signifikan terhadap pertumbuhan ekonomi disemua kawasan regional maupun pada level nasional. Setiap kenaikan rasio pengeluaran pemerintah sebesar 1 persen secara signifikan akan menyebabkan penurunan pertumbuhan ekonomi sebesar 0,22 persen untuk level nasional, 0,13 persen untuk kawasan barat Indonesia dan 0,29 persen untuk kawasan timur Indonesia. Temuan ini sesuai dengan penelitian Barro dan Sala-i-Martin (1997), Seleteng (2013) dan Vinayagathasan (2013). Pengeluaran pemerintah akan mengurangi investasi swasta yang lebih efisien, pada akhirnya justru akan memperlambat pertumbuhan ekonomi.

Estimasi panel fixed effect model menunjukkan bahwa inflasi berpengaruh negatif terhadap pertumbuhan ekonomi pada semua level wilayah. Namun penelitian empiris sebelumnya menunjukkan hubungan inflasi dengan pertumbuhan ekonomi ada kemungkinan tidaklah linear. Salah satu metode untuk mengidentifikasi ketidaklinearan model adalah menggunakan analisis panel threshold fixed effect model yang dikembangkan oleh Hansen (1999).

Hasil uji signifikansi threshold menunjukkan hubungan inflasi dengan pertumbuhan ekonomi di Indonesiatidaklah liniear. Uji keberadaan threshold menemukan bahwa nilai threshold untuk wilayah Indonesia ternyata tidak hanya satu melainkan dua. Jika uji keberadaan threshold hanya mencari satu nilai, ditemukan nilai threshold sebesar 9,59 persen, signifikan pada taraf nyata 5 persen. Sementara jika uji keberadaan threshold mencari dua nilai ditemukan nilai threshold sebesar 5,09 persen dan 9,57 persen, signifikan pada taraf nyata 1 persen.

Inflasi berpengaruh positif namun tidak signifikan terhadap pertumbuhan ekonomi saat berada dibawah nilai threshold 9,59 persen, namun saat berada diatas nilai threshold 9,59 persen, inflasi di Indonesia berpengaruh negatif dan signifikan terhadap pertumbuhan ekonomi.

Sementara jika menganalisis dua threshold, inflasi berpengaruh positif namun tidak signifikan terhadap pertumbuhan ekonomi saat berada dibawah nilai threshold 5,09 persen dan diantara nilai threshold 5,09 dan 9,57 persen. Sedangkan

Tabel 4. Hasil Uji Signifikansi Threshold di Indonesia

\begin{tabular}{lcc}
\hline \multicolumn{1}{c}{ Keberadaan Nilai Threshold } & Nilai Threshold & Probabilitas \\
\hline Single Threshold & $9,59 \%$ & 0,022 \\
Double Threshold & $5,09 \%$ dan $9,57 \%$ & 0,000 \\
\hline
\end{tabular}

Sumber: Hasil Olahan Penulis

Tabel 5. Hasil Estimasi Model Threshold Inflasi di Indonesia

\begin{tabular}{lcc}
\hline \multicolumn{1}{c}{ Variabel dependen : Pertumbuhan Ekonomi } & Koefisien & Probabilitas \\
\hline Single Threshold & & 0,677 \\
Inflasi $\leq 9,59$ & 0,024 & 0,000 \\
Inflasi $>9,59$ & $-0,127$ & \\
Double Threshold & & 0,591 \\
Inflasi $\leq 5,09$ & 0,076 & 0,401 \\
$5,09<$ Inflasi $\leq 9,57$ & 0,059 & 0,000 \\
Inflasi $>9,57$ & $-0,125$ & \\
\hline
\end{tabular}

Sumber: Hasil Olahan Penulis 
saat inflasi berada diatas nilai threshold 9,57 persen, inflasi di Indonesia berpengaruh negatif dan signifikan terhadap pertumbuhan ekonomi. Jika dilihat koefisien dari inflasi dibawah threshold 5,09 nilainya lebih tinggi saat dibandingkan dengan koefisien inflasi diantara threshold 5,09 dan 9,57. Hal tersebut menunjukkan inflasi menyebabkan perlambatan pertumbuhan ekonomi saat nilainya melebihi 5,09 persen. Namun saat inflasi melebihi 9,57 persen, pertumbuhan ekonomi bukan hanya melambat namun menurun.

\section{KESIMPULAN DAN SARAN}

Inflasi berpengaruh negatif signifikan terhadap pertumbuhan ekonomi disemua kawasan regional maupun pada level nasional. Uji keberadaan threshold menemukan bahwa nilai threshold untuk wilayah Indonesia ternyata tidak hanya satu melainkan dua. Jika uji keberadaan threshold hanya mencari satu nilai ditemukan nilai threshold sebesar 9,59 persen. Sementara jika uji keberadaan threshold mencari dua nilai ditemukan nilai threshold sebesar 5,09 persen dan 9,57 persen.

Inflasi berpengaruh negatif signifikan terhadap pertumbuhan ekonomi di Indonesia saat melebihi 9,59 persen dan 9,57 persen. Sementara pertumbuhan ekonomi di Indonesia sedikit melambat saat inflasi melebihi 5,09 persen, walaupun secara statistik tidak signifikan.

Studi ini menyarankan pihak terkait seperti Bank Indonesia (BI) dan Tim Pemantauan dan Pengendalian Inflasi Daerah (TPID) untuk berhati-hati saat inflasi mulai melebihi angka 5,09 persen dan waspada saat inflasi melebihi angka 9,57 persen dan 9,59 persen.

\section{UCAPAN TERIMA KASIH}

Puji dan syukur Alhamdulillah penulis panjatkan kepada Allah Subhanahu wa ta'ala atas segala karunia-Nya sehingga penelitian ini berhasil diselesaikan. Terima kasih penulis ucapkan kepada Dr. Ir. Iman Sugema, M.Ec dan Dr. Syamsul H. Pasaribu, SE, M.Si selaku komisi pembimbing yang telah memberi banyak masukan, dan saran, serta motivasi. Di samping itu, penghargaan penulis sampaikan kepada segenap pimpinan dan pegawai Badan Pusat Statistik (BPS) RI, BPS Provinsi Maluku Utara, serta Pusdiklat
BPS yang telah memberikan kesempatan kepada penulis untuk melanjutkan pendidikan di Institut Pertanian Bogor (IPB). Ungkapan terima kasih juga disampaikan kepada istri tercinta Yeni, putra tersayang Rama, putri tersayang Ainun atas cinta, doa dan dorongan semangatnya, Ayah (Sujanto), Ibu (Yuni Mulyati), serta seluruh keluarga, atas segala doa dan kasih sayangnya. Untuk rekanrekan Program Pascasarjana Ilmu Ekonomi IPB kelas BPS batch 5, 6 dan 7, terimakasih atas diskusi dan ilmu yang dibagikan.

\section{DAFTAR PUSTAKA}

Andres J, Hernando I. 1997. Does inflation harm economic growth? Evidence from OECD (Working Paper No. 6062). Cambridge, MA: National Bureau of Economics Research.

Aziz E B, Nasrudin. 2016. Estimation Threshold Inflation in Indonesia. Journal of Applied Economic Sciences. 7(45):1376-1383.

Barro R J. (1996). Inflation and growth. Federal Reserve Bank of St. Louis Review, 78(3), 153-169.

Barro R J, Sala-i-Martin X. (2004). Economic Growth Second Edition. London (GB): The MIT Press.

Behera J. (2014). Inflation and its impact on economic growth: Evidence from six South Asian countries. Journal of Economics and Sustainable Development, 5(7), 145-154.

Cameron N, Hum D, Simpson W. (1996). Stylized facts and stylized illusions inflation and productivity revisited. Canadian Journal of Economics, 29(1), 152-162.

Chowdhury A, Ham R. (2009). Inflation Targeting in Indonesia: Searching for a Threshold. The Singapore of Economic Review. 54(4):645655.

Chowdhury A, Siregar H. (2004). Indonesia's Monetary Policy Dilemma: Constraints of Inflation Targeting. The Journal of Developing Areas.37(2): 137-153.

De Gregario J. (1992). Effects of inflation on economic growth: Lession from Latin America. European Economic Review, 36(April), 417-425. 
Dorrance S. (1963). The effects of inflation on economic development. Staff Papers, International Monetary Fund, 1(10), 1-47.

Enders W. (2015). Applied Econometric Time Series. New York (US): John Wiley \& Sons Inc.

Fischer S. (1993). Inflation and Growth. Working Paper No. 1235. National Berau of Economics Research.

Friedman M. (1956). Quantity theory of money: A restatement. In M. Frideman (Ed.), Studies in the quantity theory of money (pp. 3-21). Chicago, IL: University of Chicago Press.

Gokal V, Hanif S. (2004). Relationship between inflation and economic growth. Working Paper 2004/04. Reserve Bank of Fiji.

Gylfason T. (1998). Output gains from economic stabilization. Journal of Development Economics, 56(1), 81-96.

Hansen. (1997). Inference in TAR models. Studies in Non-Linear Dynamics and Econometrics. 2(1): 1-14.

. (1999). Threshold effects in non-dynamic panels: estimation, testing, and inference. Journal of Econometrics. 93(2):345-368.

Mallik G, Chowdhury A. (2001). Inflation and economic growth: Evidence from South Asian countries. Asian Pacific Development Journal, 8(1), 123-135.

Ndoricimpa A. (2017). Threshold Effects of Inflation on Economic Growth in Africa: Evidence from a Dynamic Panel Threshold Regression Approach. Working Paper Series No. 249. African Development Bank.

Saeed A A J. (2007). Inflation and economic growth in Kuwait 1985-2005: Evidence from coinetgration and error correction model. Journal of Applied Econometrics and International Development, 7(1), 143-155.
Shi S. (1999). Search, inflation and capital accumulation. Journal of Monetary Economics, 44(1), 81-103.

Sidrauski M. (1967). Rational choice and patterns of growth in a monetary economy. American Economic Review, 57(2), 534-544.

Stockman A C. (1981). Anticipated inflation and the capital stock in a cash advance economy. Journal of Monetary Economics, 8(3), 387-393.

Sukirno S. (2012). Pengantar Teori Ekonomi Makro Edisi ke 3. Jakarta (ID): PT. RajaGrafindo Persada.

Sweidan O. (2004). Does Inflation Harm Economic Growth in Jordan? An Econometric Analysis for the Period 1970-2000. International Journal of Applied Econometrics and Quantitative Studies. 1(2)

Tobin J. (1965). Money and economic growth. Econometrica, 33(4), 671-684.

Todaro MP, Smith SC. (2009). Economic Development. Boston (US): Pearson.

Utari D., Cristina R., Pambudi S. 2016. Inflasi di Indonesia: Karakteristik dan Pengendaliannya. Jakarta: BI Institute.

Vinayagathasan T. (2013). Inflation and Economic Growth: A Dynamic Panel Threshold Analysis for Asian Economies. Journal of Asian Economics, 26, 21-41.

Warjiyo P, Juhro SM. (2016). Kebijakan Bank Sentral: Teori dan Praktik. Jakarta (ID): Rajawali Press

Widaryoko N. (2013). Inflasi dan Pertumbuhan Ekonomi: Pendugaan Ambang Batas Inflasi di Indonesia [tesis]. Bogor (ID): Institut Pertanian Bogor. 